KeMAS 16 (2) (2020) 154-162
Jirnal Kesehatan Masyarakat

\title{
Mobile Health Quality among National Health Insurance Participants in South Sumatra
}

\author{
Haerawati Idris ${ }^{\bowtie}$, Misnaniarti, Dian Safriantini \\ Department of health policy \& Administration, Faculty of Public Health, Sriwijaya University
}

\begin{tabular}{l} 
Article Info \\
\hline Article History: \\
Submitted Oktober 2019 \\
Accepted June 2020 \\
Published November 2020 \\
\hline Keywords: \\
Mobile health, quality, \\
national health insurance \\
\hline DOI \\
https://doi.org/10.15294/ \\
kemas.v16i2.21357
\end{tabular}

\begin{abstract}
The development of information technology and telecommunications has penetrated into various sectors including health. With Mobile JKN, community administrative activities in managing JKN are easier. The study aims to analyze the perception of mobile health among participants JKN in South Sumatra Province. This research is a quantitative study with a cross-sectional design. The research sample was JKN participants stay in South Sumatra aged $>18$ years who use the Mobile JKN app amount 400 participants. The sampling technique used purposive sampling. Data collection using online questionnaires and distributed through social media. Results of the study showed that the perception of the quality system has optimal results (50,50\%). The problem encountered was in the network stability indicator from JKN mobile application users. On the quality of information has optimal results (67.50\%). Problems encountered are in the indicator of limited service information, display updates. Then, the quality of service has optimal results $(63,50 \%)$. The problem encountered was in the service integration indicator from the JKN mobile application. Quality of the JKN Mobile application seen from the System Quality, Information Quality and Service Quality has optimal results. BPJS Health suggested to increase network stability, improve service information, display updates and information in the JKN Mobile application, conduct application socialization, and develop service integration.
\end{abstract}

\section{Introduction}

The development of information technology and telecommunications has penetrated into various sectors including the health sector (Habib, 2016; Tangcharoensathien; 2017). This has the potential to change the face of health services throughout the world (Yuan, 2017; Gaudette, 2018). The role of technology in the world of health is very important, especially in improving the quality and quality of health services (Mustika, 2015).

In Every year, the number of people who have participated in the National Health Insurance (JKN) continues to grow. 157.7 million in 2015, to 188.7 million in 2016, to 223 million in 2017, to 235.1 million in 2018 and to reach 257.5 million or the entire population of
Indonesia in 2019 (BPJS of Health, 2017)

The number of participants in the National Health Insurance in South Sumatra does not cover the whole community (Rahmaliyah, 2018). This shows that there are still significant challenges for the South Sumatra of social insurance administration organization or known as BPJS of Health and the South Sumatra Government to realize Universal Health Coverage in South Sumatra.

Considering the increasing number of people who use mobile technology, BPJS Health as the Indonesian Social Security Organizing Agency is not behind the idea. At the launching of the JKN Mobile application in Jakarta, the Director of the Health BPJS said that in order to improve services for participants in the 
National Health Insurance-Healthy Indonesia Card (JKN-KIS) the Health BPJS made the JKN Mobile application (Health, 2017).

This JKN Mobile Application is a form of digital transformation of the business model created by BPJS Health. From the beginning in the form of administrative activities in the Branch Office or Health Facility then converted into the form of a mobile application. With this transformation, JKN participants can carry out administrative activities anywhere and anytime without time limit (self service). In 2017 registered users Application Mobile JKN in Indonesian Andorid version of> 1 million users and applications Mobile JKN iOS version of $>2,000$ users (BPJS Kesehatan, 2017)

One study of health applications in Japan that is used mobile named iHeart. This application is based on location and heart rate. The iHeart system allows patients to send blood pressure and heart rate information to hospitals and emergency care units. Locationbased services in this application can be used in the world of health so that the patient's location is accurately known. The conclusion from this study states that iHeart can reduce the critical possibility of a patient in an emergency. This proves the use of mobile health applications can save more lives (Keikhosrokiani, 2013).

In another study conducted by $\mathrm{Yu}$, et al. (2006) in China explain that there are many adoption challenges in implementing mobile health. According to him the application must be fully integrated into the flow of clinical performance and assessment in patient care while offering easy administration and facilitating communication between health services. Another study, DeLone and McLean (2003) proposed a model for measuring the success of information systems. In the DeLone and McLean modification model the most common challenge for mobile health solutions is acceptance of quality consisting of three components: system quality, information quality and service quality. Each must be separate because it affects user satisfaction that supports the successful implementation of the information system used. Saptonoadi, et al. (2018) also conducted research on the quality and success of a health information system named Homedika. Homedika exists as a technology-based social entrepreneur that connects health workers and health facilities with the community to provide various health services (Hafner, 2017, Alesane, 2018). The results of the analysis obtained in this study is said that the assessment of quality by respondents included in the enough category (Braun, 2017; Roman, 2018).

As one of the efforts in improving health services in Indonesia, especially in South Sumatra, Mobile JKN is expected to be a priority application by the community. With Mobile JKN, the public can find all information related to JKN participant data including medical history, billing information and availability of health care facilities (Handayani, et al, 2018). The facilities offered by Mobile JKN can facilitate community administrative activities in managing JKN problems. This research aims to investigate of JKN participants' perceptions about the quality of Mobile JKN applications in South Sumatra as measured by: the level of system quality, quality, information and service quality.

\section{Method}

The design of this study uses quantitative cross-sectional. The sampling method used in this study was purposive sampling with human inclusion criteria of at least 18 years and had used the JKN Mobile application. The number of samples obtained was 400 . The type of collection used in this study was primary data obtained through an online questionnaire to JKN Participants in South Sumatra. The online questionnaire was created using Google Form. The collection method used in this research is to use an online questionnaire distributed via social media such as WhatsApp, LINE, Facebook, Instagram and others. The researcher distributed questionnaire links on the researchers' private social media. With the aforementioned criteria, prospective respondents who feel that they meet the criteria can fill out the questionnaire by pressing the questionnaire link listed.

Data processing obtained from the results of an online questionnaire with respondents was carried out with the following stages: 1). Gather all data obtained from respondents through an online questionnaire using Google Forms. 2). Compile data online questionnaire results that 
have been categorized using a Likert scale with a value of 1 (strongly disagree), 2 (disagree), 3 (normal), 4 (agree) and 5 (strongly agree).3). Categorizing the value if $\leq$ mean / median is the "Not optimal" category and the value if $>$ mean / median is the "optimal" category then a percentage is calculated to analyze the difference in proportions between the optimal or not optimal categories. This study refers to a standardized questionnaire from the research of Handayani, et al. (2018) with the title "Critical Success Factors for Mobile Health Implementation in Indonesia".

\section{Results and Discussion}

Subjects in this study were JKN participants domiciled in South Sumatra, aged at least 18 years and had used the JKN Mobile application. Based on the research sample obtained by the description of research subjects by sex, domicile, frequency of use of the Mobile JKN application, selected primary health facilities, features often used in the Mobile JKN application, and problems that are often experienced when using the Mobile JKN application.

Based on the picture 1, it appears that the most respondents are Age 36-45 Years $(31,75 \%)$. Based on the picture 2, it appears that the most respondents are Women (61\%). Based on the picture 3, it appears that the most respondents are with a bachelor's degree (48\%). Based on the picture 4, it appears that the most respondents are civil servant/Indonesian National Army/Indonesian Police/SOE (37, $75 \%)$. Based on the picture 5, it appears that the most respondents are staying the city of Palembang (37, $5 \%$ ). Based on the picture 6, it appears that the most respondents using

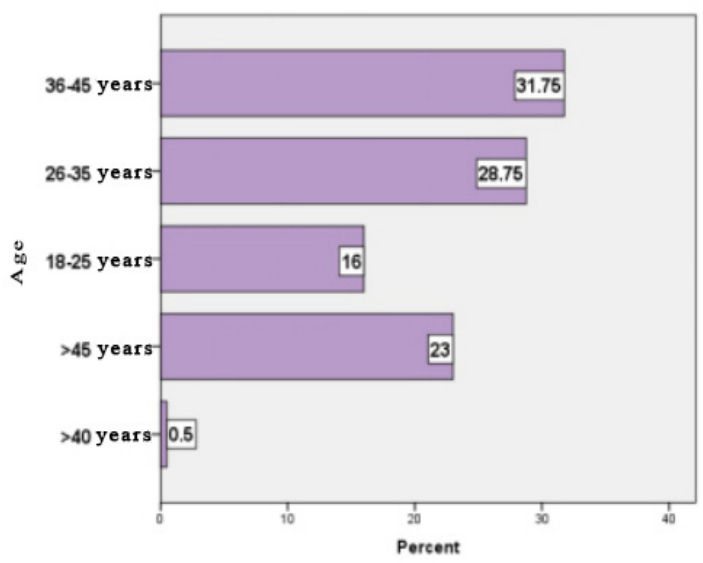

Figure 1. Diagram of Research Respondents by Age

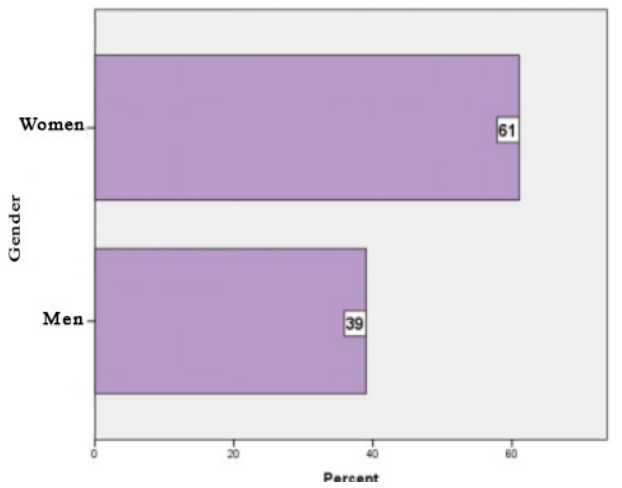

Figure 2 Diagram of Research Respondents by Gender 


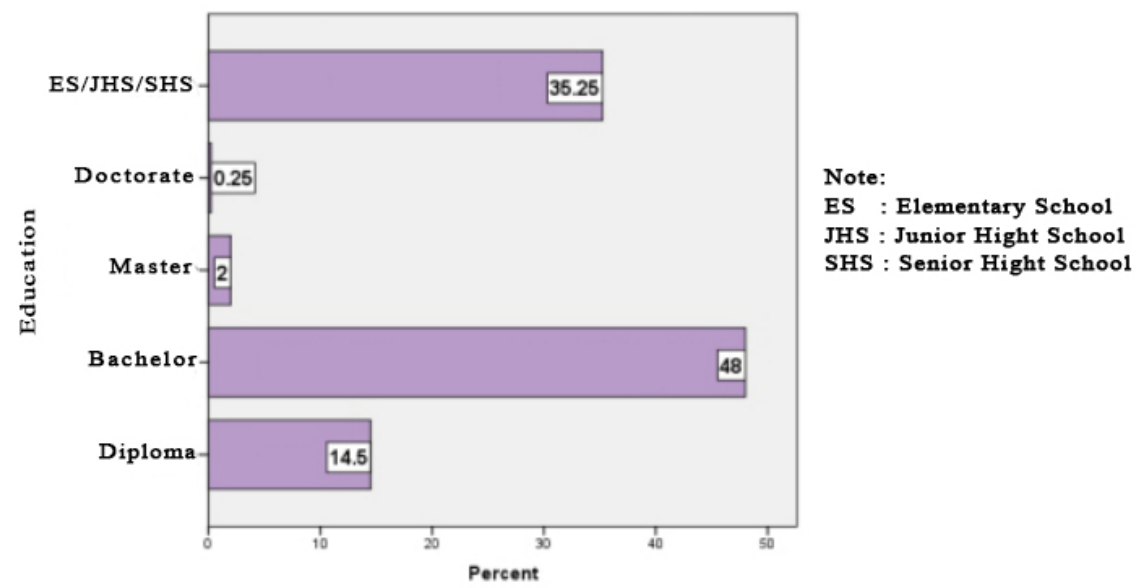

Figure 3 Diagram of Research Respondents based on Recent Education

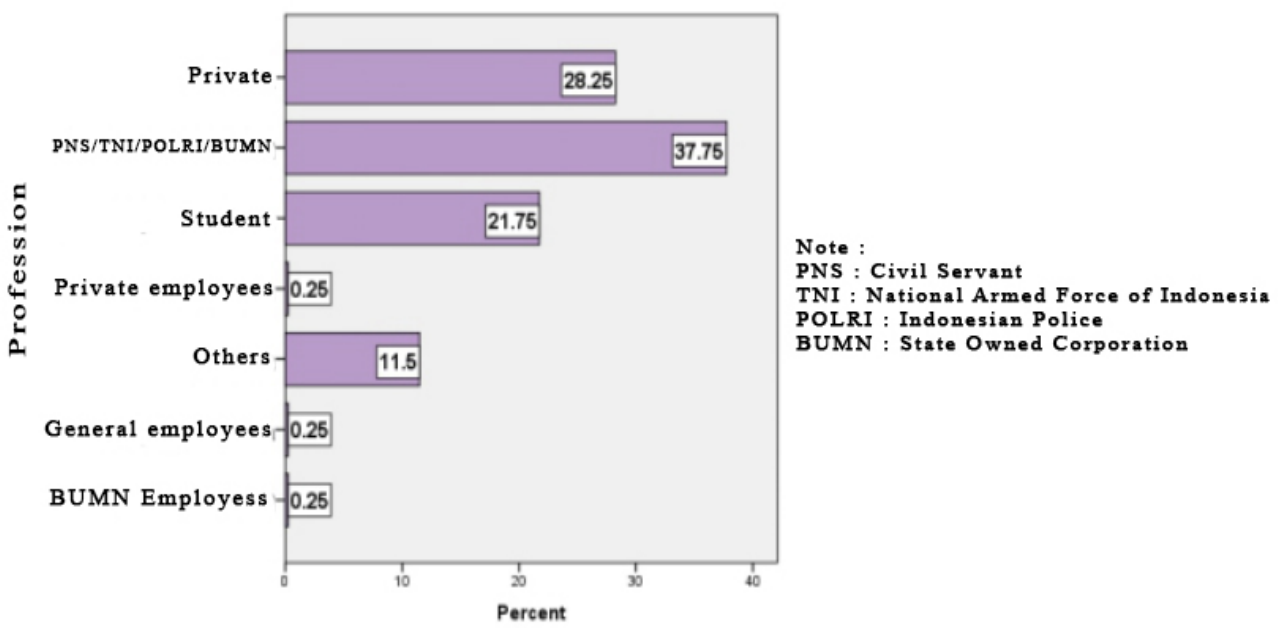

Figure 4 Diagram of Research Respondents based on Employment

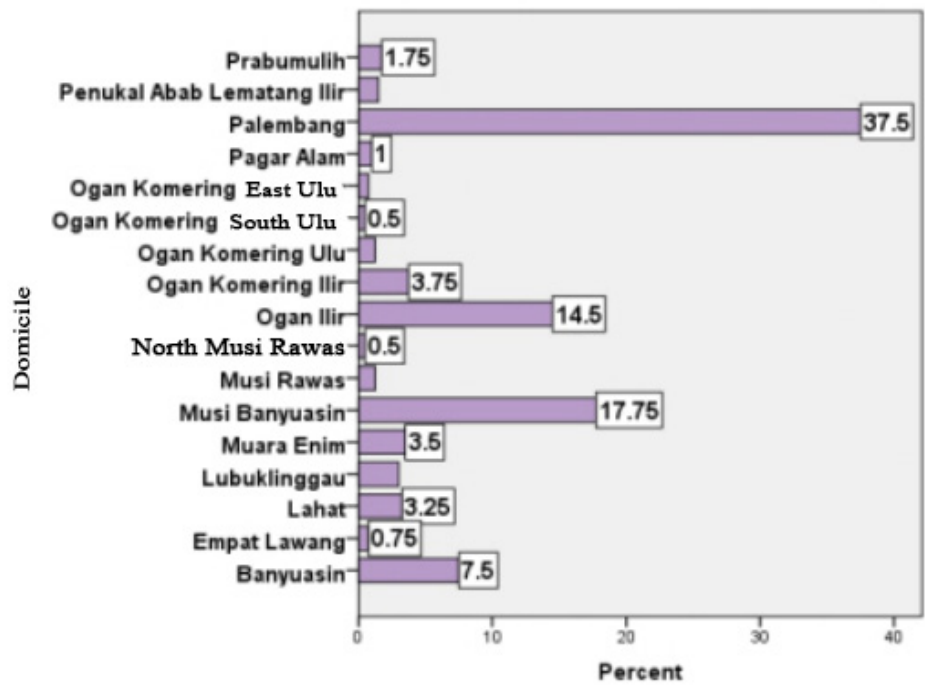

Figure 5 Diagram of Research Respondents based on living 
the Mobile JKN application in the last 3 months are 1-5 times (97.25\%). Based on the picture 7 , it can be seen that the most respondents are participants with primary health facilities Clinic / Practitioner (52\%).

Based on the results of responses that have been collected, the following is the respondent's assessment of the quality of the system: Based on the total question "Quality of the System" on the research subjects, it was found that the Quality of the System has optimal results (50.50\%).

Respondents who fill out an online questionnaire can fill out suggestions or comments about the Mobile JKN application in the column that has been provided in the online questionnaire link. Below are the sentences written by respondents regarding the quality of the JKN Mobile application system:

"If the network becomes unstable the response will be slow"

"Application response please accelerate"

"The need for internet data to access Mobile JKN is not too big please"

Based on the above sentence, it can be concluded that the outline of suggestions or comments from respondents is about network stability from using the JKN Mobile application.

Based on the results of responses that have been collected, the following is the respondent's assessment of the quality of information. Based on the total question "Information Quality"

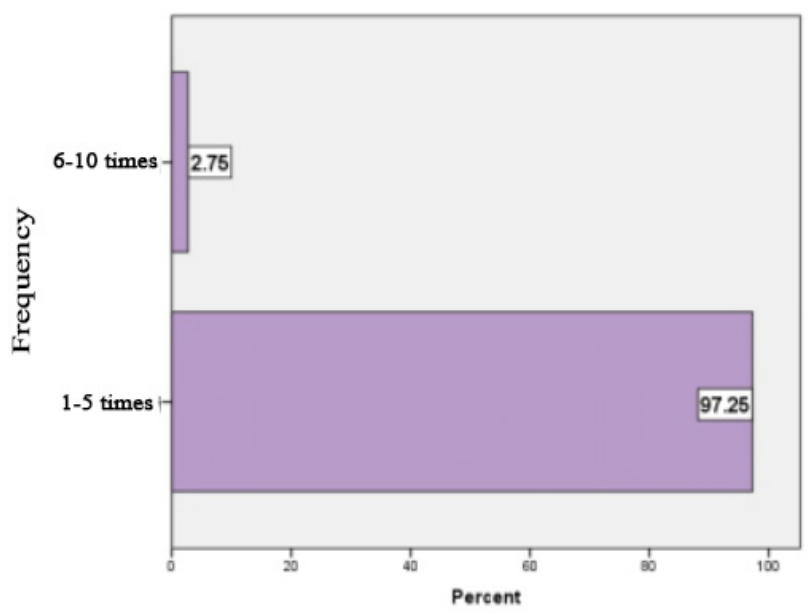

Figure 6 Diagram of Research Respondents Based on Frequency of Use of JKN Mobile Application

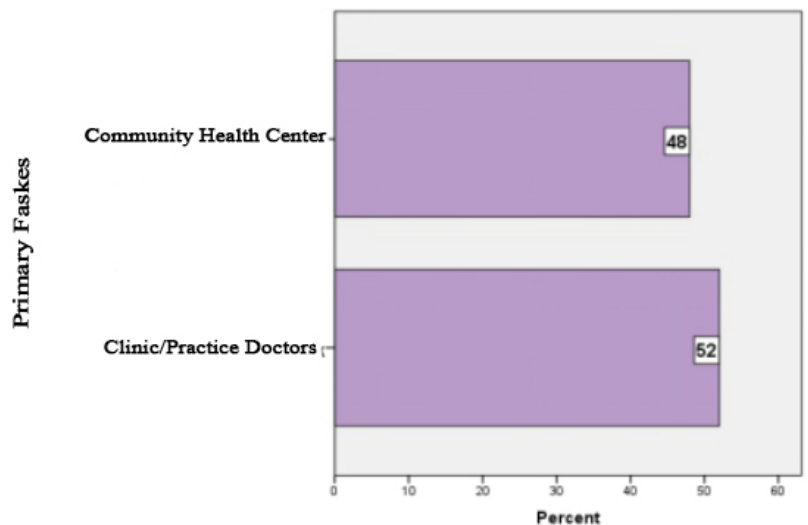

Figure 7 Diagram of Research Respondents Based on Primary Health Facilities 
on the research subjects, it was found that Information Quality has Optimal results $(67,50 \%)$.

Respondents who fill out an online questionnaire can fill out suggestions or comments about the Mobile JKN application in the column that has been provided in the online questionnairelink. Below are sentences written by respondents regarding the quality of information on the JKN Mobile application:

"Please enter information about
health services that are covered and
not covered by JKN"
"In order to list the types of medicines
that can be obtained from the use of
JKN-KIS"
"Update the appearance of the JKN
Mobile application"
"The need to update data and
information on JKN membership
regularly"
"Data updates are sometimes late"
"Update mapping of health facility
locations"
"Provide socialization so that use can
be wider"
"There needs to be more outreach to
the community"
"The existence of Mobile JKN must be
increased"
"Please carry out ongoing promotions
related to services within the
application"

Based on the sentences above, it can be concluded an outline of suggestions or comments from respondents is about service information, display updates and information as well as organizing the socialization of the Mobile JKN application. Based on the total "Service Quality" questions on the research subjects, it was found that the Quality of the System had Optimal results (63,50 \%).

Respondents who fill out an online questionnaire can fill out suggestions or comments about the Mobile JKN application in the column that has been provided in the online questionnaire link. Below are sentences written by respondents regarding the quality of Mobile JKN application services:

"Please add Mobile JKN features to register online for referrals to hospitals"

Based on the above sentence, it can be concluded that the outline of suggestions or comments from respondents is about developing service integration from the Mobile JKN application.

The quality of information systems is a characteristic of inherent information about the system itself (DeLone and McLean, 1992). The quality of information systems is also defined by Davis et al. (1989) as perceived ease of use that is the level of how great technologist i computer felt relatively easy to understand and use. This shows that if information system users feel that using the system is easy, they don't need much effort to use it, so there will be more time to do other things.

Based on the results of the total System Quality questions, the System Quality has an Optimal result $(50,50 \%)$. The results of this study are different from the results of research Saptonoadi, et al. (2018) and Saragih, et al. (2014) who also said that the quality of the application system under study had suboptimal results.

After analyzing the system quality questions from the respondents' assessment scores, the most chose Very Disagree as many as 3 people found in question 1 (I find it easy to monitor activities related to BPJS Health using Mobile JKN). That is, some respondents still have difficulty in monitoring activities related to the Health BPJS through the JKN Mobile application. Respondents who chose the most Disagree as many as 5 people are in question 5 (Mobile JKN provides a fast system response time in its use). That is, some respondents felt that the response time of the Mobile JKN system was still slow. Then, the 33 people who chose the Strongest Agree as many as there are in question 6 (Mobile JKN gives me ease in making decisions in its application, for example to replace primary health facilities). That is, some respondents have felt the Mobile JKN application makes it easy to make decisions in their application such as changing primary health facilities.

Based on the results obtained, it was concluded that the quality of 
the Mobile JKN application system was not optimally assessed from the perspective of students who used the Mobile JKN application. Problems encountered were in the indicators "ease of monitoring activities" and "system response time". In this case, BPJS Health needs to improve application performance in making it easier for users to monitor activities related to BPJS Health and the application system response time.

Information quality is the quality of output in the form of information produced by the information system used (Istianingsih, 2009). The better the quality of information, would be more appropriate decisions anyway. If the information produced is not quality, it will negatively affect user satisfaction which determines the optimization of the information system.

Based on the results of the total information questions Quality Information, obtained Information Qualityhas optimal results $(67,50 \%)$. The results of this study are different from the results of research Saptonoadi, et al. (2018) and Saragih, et al. (2014) who also said that the quality of the application system under study had suboptimal results.

After analyzing the information quality questions from the respondent's assessment score, the most chose Disagree as many as 7 people found in question 6 (Mobile JKN provides information that is always updated ) and 5 people in question 2 (Information in Mobile JKN matches the physical documents that I have possess (for example BPJS identity card number) This means that some respondents still feel that the Mobile JKN application has not provided information that is always updated and some respondents still feel that the information in Mobile JKN does not match the physical documents that the respondent has. Strongly Agree as many as 34 people are in question 2 (Information in Mobile JKN is in accordance with the physical documents that I have, for example BPJS identity card number), meaning that some respondents have felt that the information in Mobile JKN is in accordance with the physical documents that the respondent has.

Based on the results obtained, it was concluded that the quality of the Mobile JKN application information was not optimally assessed from the perspective

JKN Mobile application user students. The problems encountered are on the indicators "information that is always updated" and "sufficient and relevant information". In this case, BPJS Health needs to improve application performance in terms of periodic updating of information contained in JKN Mobile.

Service quality is the user's perception of the services provided by the accounting application program package provider. Initially this service quality measure was designed to measure customer satisfaction by Parasuraman, Zeithaml and Berry (1988). They define service quality as a comparison between customer expectations and their perception of the quality of customer service provided.

Based on the results of the total question data, it is obtained that the Quality of Service has optimal results $(63.50 \%)$. The results of this study are different from the results of research Saptonoadi, et al. (2018) and Saragih, et al. (2014) who also said that the quality of the application system under study had suboptimal results .

After analyzing the service quality questions from the respondents' score, most of them choose Disagree 4 people to question 6 (Mobile JKN provides consistent services without problems or obstacles). That is, some respondents feel Mobile JKN still has obstacles in providing its services. Then, the most voted Very Agree as many as 25 people is in question 3 (Mobile JKN offers continuous improvements to the provision of services). That is, some respondents were satisfied with the offer of improvements in the JKN Mobile application.

Based on the results obtained, it was concluded that the service quality of the Mobile JKN application was not optimally assessed from the perspective of students who used the Mobile JKN application. The problems encountered are on the indicator "consistent service availability". In this case, BPJS Health needs to improve application performance in providing consistent services by minimizing obstacles in the service of officers and users through the JKN Mobile application.

\section{Conclusion}


Based on a survey of users of the Mobile JKN application on National Health Insurance participants in South Sumatra, it is known that: Characteristics of the respondents of this study are the majority of women $(60 \%)$, domiciled in Palembang $(41.2 \%)$, with a frequency of application usage 1-5 times in the last 3 months $(87.7 \%)$, with public health center as the primary health facility selected (51.3\%), with the feature most frequently used in the application was about JKN information (50.4\%), and the most frequently experienced problems when using an application is not knowing the functions and services provided (70.6\%). System Quality has optimal results $(57,46 \%)$. Based on data from the results of the online questionnaire, problems encountered were found in the indicators of the ease of monitoring activities and system response time. Information Quality has Optimal results $(60,53 \%)$. Based on data from the results of the online questionnaire, the problem found is in the information indicator that is always updated and sufficient and relevant information. Service Quality has optimal results $(58,77 \%)$. Based on data from the results of the online questionnaire, the problems encountered are in the indicators of consistent service availability. It is expected to BPJS South Sumatra to consider doing: doing development between BPJS service integration with health facilities for the sake of application utilization Mobile JKN much better.

\section{References}

Alesane, A., \& Anang, B. T. (2018). Uptake of health insurance by the rural poor in Ghana: determinants and implications for policy. The Pan African medical journal, 31, 124. https:// doi.org/10.11604/pamj.2018.31.124.16265

BPJS Kesehatan. (2017). Akses Pelayanan dalam Genggaman : BPJS Kesehatan Luncurkan Aplikasi Mobile JKN.

Braun, R. T., Hanoch, Y., \& Barnes, A. J. (2017). Tobacco use and health insurance literacy among vulnerable populations: implications for health reform. BMC health services research, 17(1), 729. https://doi.org/10.1186/ s12913-017-2680-7

Critical Success Factors for Mobile Health Implementation in Indonesia. Heliyon 2018;4(11):e00981 Published2018 Nov 27. doi:10.1016/j.heliyon.2018.e00981

Davis, Gardon. B. (1992). Sistem Informasi
Manajemen. Jakarta: Pustaka Bianaman Pressindo.

DeLone, W., McLean, E. 2003. The Delone And Mclean Model of Information Systems Success: A Ten-Year Update, J. Manag. Inf. Syst. 19 (4) (2003) 9e30.

Gaudette, É., Pauley, G. C., \& Zissimopoulos, J. M. (2018). Lifetime Consequences of Early-Life and Midlife Access to Health Insurance: A Review. Medical care research and review : MCRR, 75(6), 655-720. https://doi. org/10.1177/1077558717740444

Habib SS, Perveen S, Khuwaja HM. The role of micro health insurance in providing financial risk protection in developing countries-a systematic review. BMC Public Health. 2016 Mar 22;16:281. doi: 10.1186/s12889016-2937-9. PMID: 27004824; PMCID: PMC4802630.

Hafner Z. (2017). The Health Insurance Conundrum: Crossing the Divide. Managed care (Langhorne, Pa.), 26(10), 31.

Istianingsih \& Utami W. (2009). Pengaruh Kepuasan Pengguna Sistem Informasi Terhadap Kinerja Individu. Simposium Nasional Akuntansi XII, 1-70

Keikhosrokiani. P, N. Mustaffa, N. Zakaria, M. Sarwar. (2013). Wireless positioning techniques and location-based services: a literature review: J. Park, J.Y. Ng, H.Y. Jeong, B. Waluyo (Eds.). Multimedia and Ubiquitous Engineering. Lecture Notes in Electrical Engineering, 240, Springer, Dordrech

Mustika, Meryl. (2015). Perkembangan Teknologi Informasi dalam Aspek Kesehatan. Yogyakarta: UGM Press

Parasuraman, A., V.A. Zeithaml \& L.L. Berry. 1988. Servqual: A Multiple- Item Scale for Measuring Consumer Perceptions of Service Quality. Journal of Retailing, 64(1): 12-40

Rahmaliyah, 2018 Survey Peserta JKN-KIS.

Roman-Urrestarazu, A., Yang, J. C., Ettelt, S., Thalmann, I., Seguel Ravest, V., \& Brayne, C. (2018). Private health insurance in Germany and Chile: two stories of co-existence, segmentation and conflict. International journal for equity in health, 17(1), 112. https://doi.org/10.1186/s12939-018-0831-z

Saptonoadi, C., Herlambang, A., \& Wijoyo, S. 2018. Kualitas dan Kesuksesan Implementasi Sistem Informasi Kesehatan dengan Menggunakan Model Unified Theory of Acceptance and Use of Technology dan Model Delone and Mclean. Jurnal Pengembangan Teknologi Informasi dan Ilmu Komputer, vol. 2, no. 12, p. 6386-6390, agu. 2018. ISSN 2548-964X. 
Saragih, Hoga \& Safariana, Siti. 2014. Analisis Kualitas Aplikasi Online Berbasis Web pada Perum Perumnas. Journal of Information System Vol. 10.

Tangcharoensathien, V., Thwin, A. A., \& Patcharanarumol, W. (2017). Implementing health insurance for migrants, Thailand. Bulletin of the World Health Organization, 95(2), 146-151. https://doi. org/10.2471/BLT.16.179606

Yu, P., M. Wu, H. Yu, G. Xiao. 2006. The Challenges for The Adoption Of M- Health. In: 2006 IEEE International Conference on Service Operations and Logistics, and Informatics, Shanghai, 2006, pp. 181e186.

Yuan, B., Jian, W., He, L., Wang, B., \& Balabanova, D. (2017). The role of health system governance in strengthening the rural health insurance system in China. International journal for equity in health, 16(1), 44. https://doi. org/10.1186/s12939-017-0542-x 